
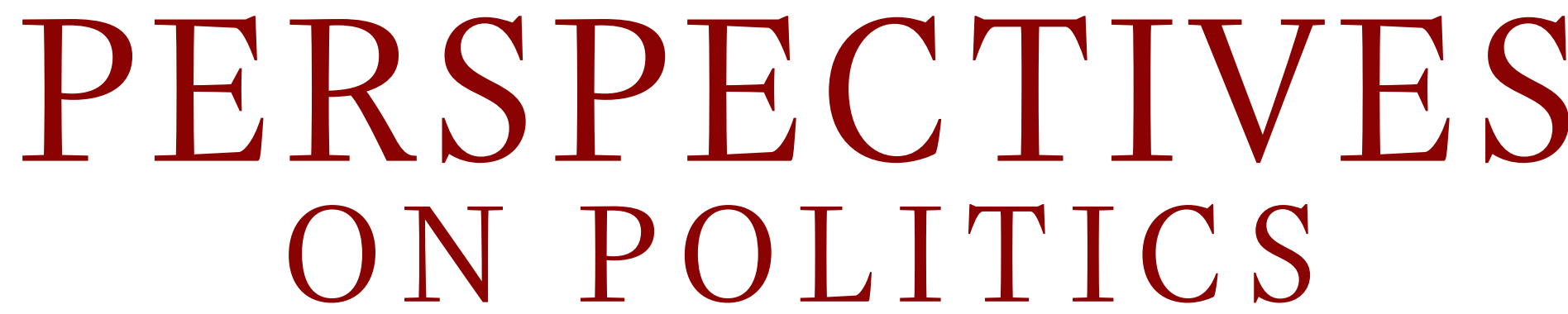

A Political Science Public Sphere | September 2020, Volume 18, Number 3

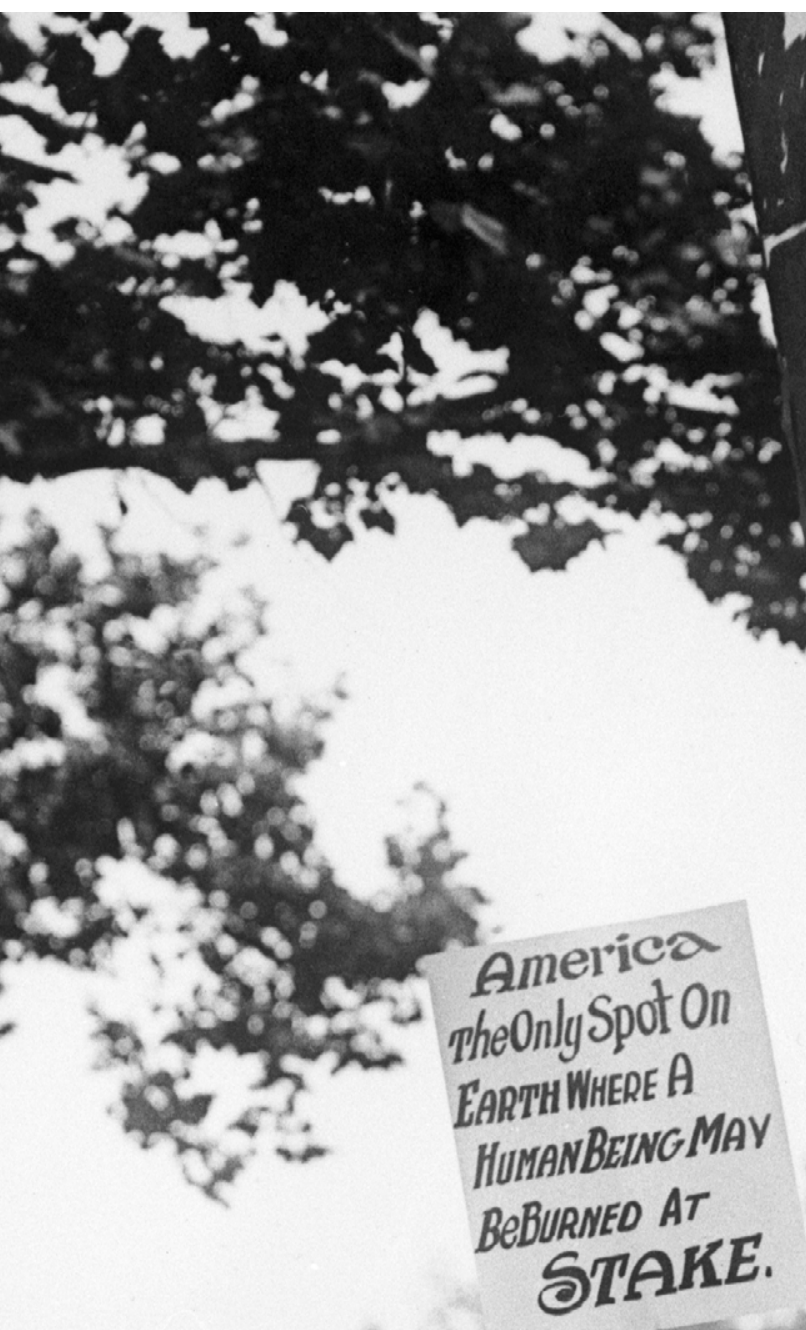




\section{용 apsaEDUCATE}

\section{Introducing APSA Educate - A Library for Political Science Teaching and Learning Resources}

APSA Educate provides a centralized space to share and access teaching materials from syllabi to simulations.

The website is free to access and features a strong search function and easy submission form. Contributing a resource takes less than ten minutes!

\section{PLATFORM BENEFITS}

- Access a broad range of high-quality political science teaching and learning materials including syllabi, in-class activities, simulations, writing assignments, civic engagement tools, and more!

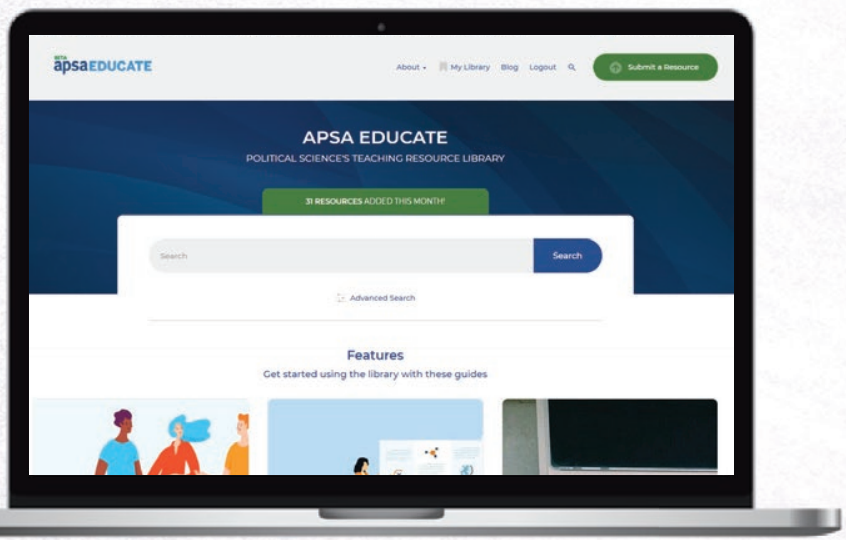

- Share your teaching materials and innovations with colleagues.

- Save favorite resources to your personal teaching resource library.

- Ask questions, discuss modifications to and experience with resources via comments.

- Learn from and share with colleagues through our Faculty Café Blog - featuring member-driven conversations around innovations, challenges, and best practices in political science education.

Learn more about APSA Educate, please visit educate.apsanet.org. 


\section{Philosophy of Perspectives on Politics}

Perspectives seeks to nurture a political science public sphere, publicizing important scholarly topics, ideas, and innovations, linking scholarly authors and readers, and promoting broad reflexive discussion among political scientists about the work that we do and why this work matters.

A full-length copy of the journal's editorial philosophy appears in Perspectives on Politics 8(1): 7-10 and also on the web at https://www.apsanet.org/perspectivessubmissions.

\section{Submission and Review}

For submission guidelines, please see https://www.apsanet.org/perspectivessubmissions.

Our editorial team discusses all submissions. Those that seem promising are eval-

uated by several external reviewers - with full confidentiality on both sides - and then accepted, returned for further revisions, or declined with suggestions of more appropriate venues for publication.

\section{CONTACT INFO}

Perspectives on Politics

Department of Political Science

1507 W. University Avenue

PO Box 117325 Anderson Hall

University of Florida

Gainesville, FL 32611

Perspectives: perspectives@apsanet.org

Book Reviews: perspectives-reviews@polisci.ufl.edu

\section{Perspectives on Politics}

Editor

Michael Bernhard, University of Florida, 2017

Associate Editor and Book Review Editor

Daniel I. O'Neill, University of Florida, 2017-

Managing Editor

Jennifer C. Boylan, University of Florida, 2017 -

Assistants to the Editor

Stephanie Denardo Karla Mundim

Marah Schlingensiepen Alec Dinnin

Editors Emeritus

Jeffrey C. Isaac, Indiana University, 2009-2017

James Johnson, University of Rochester, 2005-2008

Jennifer Hochschild, Harvard University, 2002-2005

Editorial Board

Resat Bayer, Koç University

Cristina Beltran, New York University

Richard Bensel, Cornell University

Ruth Berins Collier, University of California at Berkeley

Nancy Bermeo, Oxford University

Charli Carpenter, University of Massachusetts, Amherst

Simone Chambers, University of California, Irvine

Katherine Cramer, University of Wisconsin-Madison

Zsolt Enyedi, Central European University

Michael Goodhart, University of Pittsburgh

Anna Grzymala-Busse, Stanford University

Michael Hanchard, University of Pennsylvania

Juliet Hooker, Brown University

Jane Junn, University of Southern California

Daniel Kapust, University of Wisconsin-Madison

Douglas Lemke, Penn State University

Julia Lynch, University of Pennsylvania

Marc Lynch, George Washington University

Samantha Majic, John Jay College, CUNY

Kathleen McNamara, Georgetown University

Suzanne Mettler, Cornell University

Jørgen Møller, Aarhus University

Cas Mudde, University of Georgia

Anja Neundorf, University of Glasgow

Daniel Nexon, Georgetown University

Erin O'Brien, University of Massachusetts, Boston

Michael Leo Owens, Emory University

Christopher Parker, University of Washington

Andrew Sabl, University of Toronto

Ed Schatz, University of Toronto

Dan Slater, University of Michigan

Joe Soss, University of Minnesota

Paul Staniland, University of Chicago

Joan C. Tronto, University of Minnesota

Ashutosh Varshney, Brown University

Vesla Weaver, Johns Hopkins University

Deborah J. Yashar, Princeton University
Association Office Address and Membership Information: American Political Science Association individual membership dues are as follow: Regular members with income $\$ 200,000+$ $\$ 325 ; \$ 135,000-\$ 199,999, \$ 276 ;$ \$100,000 - \$134,000, \$246; $\$ 80,000-\$ 99,999, \$ 212 ; \$ 60,000-\$ 79,999, \$ 191 ; \$ 50,000$ $-\$ 59,999, \$ 175 ; \$ 40,000-\$ 49,999, \$ 145$; less than $\$ 40,000$, $\$ 98$; Retired members with income $\$ 25,000+, \$ 66$; Retired members with income less than \$25,000, \$40; Targeted international member (TIM), \$45; Life member, \$4,000; K -12 (PS only), \$50; Unemployed members, \$45; Student members, \$52; Associate member with one journal selection, \$75. Changes of address for members should be completed online or mailed to the APSA membership office at: APSA, 1527 New Hampshire Avenue, N.W., Washington, DC 20036

Subscription, Publishing, and Advertising Office Address: Cambridge University Press, One Liberty Plaza, Floor 20, New York, NY 10006; and (for correspondents outside the United States, Canada, and Mexico) Cambridge University Press, Journals Fulfillment Department, UPH, Shaftesbury Road, Cambridge CB2 8BS, England.

Subscription Information: Perspectives on Politics (ISSN 1537 5927) is published quarterly, in March, June, September, and December, by Cambridge University Press (One Liberty Plaza, 20th floor, New York, NY 10006) for the American Political Science Association. Annual institutional electronic-only subscription rate (2020) is US\$1642 in the United States, Canada, and Mexico; £943 elsewhere. Annual institutional print and electronic subscription rate (2020) is US\$1903 in the United States, Canada and Mexico; £1080 elsewhere. Perspectives on Politics is sold only as part of a joint subscription with the American Political Science Review and PS: Political Science \& Politics. Single part rate (2020) is US\$201 in the United States, Canada and Mexico; £114. elsewhere. Periodicals postage rate paid at New York, NY, and additional mailing offices

Postmaster: Send address changes to Perspectives on Politics, Cambridge University Press, Journals Fulfillment Department One Liberty Plaza, Floor 20, New York, NY 10006, U.S.A Send address changes elsewhere to Perspectives on Politics, Cambridge University Press, Journals Fulfillment Department, UPH, Shaftesbury Road, Cambridge CB2 8BS, England.

(c) American Political Science Association 2020.

All rights reserved. No part of this publication may be reproduced, in any form or by any means, electronic, photocopying, or otherwise, without permission in writing from Cambridge University Press. Policies, request forms, and contacts are available from: http://www.cambridge.org/rights/permissions/ permission.htm

Permission to copy (for users in the U.S.A.) is available from the Copyright Clearance Center, http://www.copyright.com email: info@copyright.com.

Advertising: Perspectives on Politics has a circulation of 16,000. For information on advertising rates and mechanical requirements, contact Advertising Coordinator, Cambridge University Press, One Liberty Plaza, Floor 20, New York، NY 10006. (212) 337-5000

Composition: SPI Global

Printing and Distribution: The Sheridan Press, Hanover, PA. 


\section{About APSA}

Founded in 1903, the American Political Science Association is the leading professional organization for the study of political science and serves more than 12,000 members in over 80 countries. With a range of programs and services for individuals, departments, and institutions, APSA brings together political scientists from all fields of inquiry, regions, and occupational endeavors within and outside academe in order to deepen our understanding of politics, democracy, and citizenship throughout the world.

The direct advancement of knowledge is at the core of APSA activities. We promote scholarly communication in political science through a variety of initiatives including publishing four distinguished journals: American Political Science Review, Perspectives on Politics, PS: Political Science \& Politics, and the Journal of Political Science Education.

\section{Officers}

\section{PRESIDENT}

Paula D. McClain

Duke University

VICE-PRESIDENTS

Kerstin Hamann

University of Central Florida

Leonard Wantchekon

Princeton University

Melissa Williams

University of Toronto

\section{Council}

2017-2020

Joseph Carens

University of Toronto

Lisa Garcia-Bedolla

University of

California, Berkeley

Lilly J. Goren

Carroll University

Simon Jackman

University of Sydney

Johns Hopkins

University

Erin Richards

Cascadia College

Valeria Sinclair-Chapman California, Irvine

Purdue University

Laura Sjoberg

University of Florida
Matthew Kocher

\section{PRESIDENT-ELECT \\ Janet Box-Steffensmeier \\ Ohio State University}

PAST PRESIDENT

Rogers Smith

University of Pennsylvania

TREASURER

Thomas Pepinsky

Cornell University

\section{EXECUTIVE DIRECTOR}

Steven Rathgeb Smith
Frank J. Goodnow

Albert Shaw

Frederick N. Judson

James Bryce

A. Lawrence Lowell

Woodrow Wilson

Simeon E. Baldwin

Albert Bushnell Hart

W. W. Willoughby

John Bassett Moore

Ernst Freund

Jesse Macy

Munroe Smith

Henry Jones Ford

Paul S. Reinsch

Leo S. Rowe

William A. Dunning

Harry A. Garfield

James W. Garner

Charles E. Merriam

Charles A. Beard

William Bennett Munro

Jesse S. Reeves

John A. Fairlie

Benjamin F. Shambaugh

Edward S. Corwin

William F. Willoughby

Isidor Loeb

Walter Shepard

Francis W. Coker

Arthur N. Holcombe

Thomas Reed Powell

Clarence A. Dykstra

Charles Grove Haines

Robert C. Brooks

Frederic A. Ogg

William Anderson

Robert E. Cushman

Leonard D. White

John Gaus

Walter F. Dodd

Arthur W. MacMahon

Henry R. Spencer

Quincy Wright

James K. Pollock

Peter H. Odegard

Luther Gulick

Pendleton Herring

Ralph J. Bunche

Charles McKinley

Harold D. Lasswell

E. E. Schattschneider

V. O. Key, Jr.

R. Taylor Cole

Carl B. Swisher

Emmette S. Redford

Charles S. Hyneman
Carl J. Friedrich

C. Herman Pritchett

David B. Truman

Gabriel A. Almond

Robert A. Dahl

Merle Fainsod

David Easton

Karl W. Deutsch

Robert E. Lane

Heinz Eulau

Robert E. Ward

Avery Leiserson

Austin Ranney

James MacGregor Burns

Samuel H. Beer

John C. Wahlke

Leon D. Epstein

Warren E. Miller

Charles E. Lindblom

Seymour Martin Lipset

William H. Riker

Philip E. Converse

Richard F. Fenno

Aaron B. Wildavsky

Samuel P. Huntington

Kenneth N. Waltz

Lucian W. Pye

Judith N. Shklar

Theodore J. Lowi

James Q. Wilson

Lucius J. Barker

Charles O.Jones

Sidney Verba

Arend Lijphart

Elinor Ostrom

M. Kent Jennings

Matthew Holden, Jr.

Robert O. Keohane

Robert Jervis

Robert D. Putnam

Theda Skocpol

Susanne Hoeber Rudolph

Margaret Levi

Ira Katznelson

Robert Axelrod

Dianne M. Pinderhughes

Peter Katzenstein

Henry E. Brady

Carole Pateman

G. Bingham Powell, Jr.

Jane Mansbridge

John H. Aldrich

Rodney E. Hero

Jennifer Hochschild

David Lake

Kathleen Thelen

Rogers Smith
Lisa Wedeen

Melanye Price

University of Chicago

Prairie View A\&M

University 


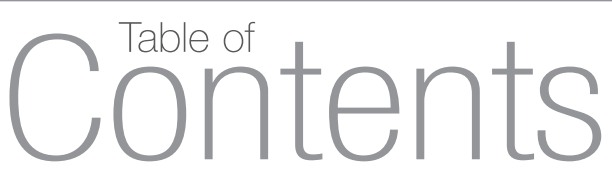

\section{From the Editors}

701 The Uses of Violence Michael Bernhard and Daniel O’Neill

\section{Special Section: The Uses of Violence}

706 The Politics of Criminal Victimization: Pursuing and Resisting Power Eduardo Moncada

722 A Path out of Patriarchy? Political Agency and Social Identity of Women Fighters Güneş Murat Tezcür

740 The Cost of Doing Politics? Analyzing Violence and Harassment against Female Politicians Mona Lena Krook and Juliana Restrepo Sanín

756 Rule by Violence, Rule by Law: Lynching, Jim Crow, and the Continuing Evolution of Voter Suppression in the U.S.

Brad Epperly, Christopher Witko, Ryan Strickler, and Paul White

770 Explaining Ethnoreligious Minority Targeting: Variation in U.S. Anti-Semitic Incidents Ayal Feinberg

788 Public Emotions and Variations of Violence: Evidence from Colombia Stacey L. Hunt

805 Reconceptualizing Political Knowledge: Race, Ethnicity, and Carceral Violence Cathy J. Cohen and Matthew D. Luttig

819 The Strange Fruit of the Tree of Liberty: Lynch Law and Popular Sovereignty in the United States Michael Gorup

835 Wait, There's Torture in Zootopia? Examining the Prevalence of Torture in Popular Movies Casey Delehanty and Erin M. Kearns

\section{Article}

851 "Tough Love": The Political Theology of Civil Disobedience Alexander Livingston

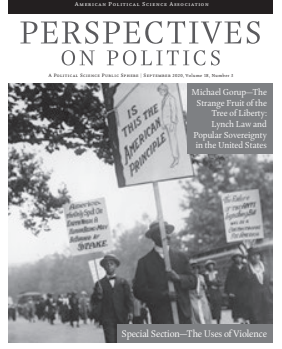

June 22, 1922. Washington, DC. Several thousand African-Americans marched silently in support of an anti-lynching bill. Such legislation was introduced over 200 times in the first half of the twentieth century. To date the United States has still not passed an anti-lynching bill. The most recent draft, the Emett Till Antilynching Act, was passed by the House of Representatives but failed to pass in the Senate by unanimous consent in June 2020. Credit: Bettmann / Contributor / Getty Images. 


\section{Reflection}

867 Demography and the Future of Democracy

Jack A. Goldstone and Larry Diamond

\section{The Book Review Section}

\section{Review Essays}

881 Anthropocene Politics

Alyssa Battistoni

886 Populism's Challenge and the Uncertain Future of Liberal Democracy

Kyong-Min Son

\section{Critical Dialogues}

893 Reviews and Responses

John J. Mearsheimer

The Great Delusion: Liberal Dreams and

International Realities

C. William Walldorf Jr.

To Shape Our World for Good: Master

Narratives and Regime Change in

U.S. Foreign Policy, 1900-2011

898 Reviews and Responses

Andrew Karch and Shanna Rose

Responsive States: Federalism and

Karen Orren and Stephen Skowronek

American Public Policy

The Policy State: An American

Predicament

903 Reviews and Responses

Daron Acemoglu and James A. Robinson

The Narrow Corridor: States, Societies,

Sheri Berman

and the Fate of Liberty

Democracy and Dictatorship in Europe:

From the Ancien Régime to the Present Day

909 Reviews and Responses

Inken von Borzyskowski

The Credibility Challenge: How Democracy Aid

Johannes Bubeck and Nikolay Marinov

Influences Election Violence

Rules and Allies: Foreign Election

Interventions

915 Reviews and Responses

T.V. Paul

Restraining Great Powers: Soft Balancing from

Joshua R. Shifrinson

Empires to the Global Era

Rising Titans, Falling Giants: How Great

Powers Exploit Power Shifts

\section{Book Reviews}

\section{POLITICAL THEORY}

921 Sonu Bedi, Private Racism

Review by Sharon Stanley

922 Filipe Carreira da Silva and Mónica Brito Vieira, The Politics of the Book: A Study on the Materiality of Ideas

Conal Condren, Political Vocabularies: Word Change and the Nature of Politics

Review by Rebecca Aili Ploof

924 Burke A. Hendrix, Strategies of Justice: Aboriginal Peoples, Persistent Injustice, and the Ethics of Political Action Review by Duncan Ivison 
Ruth Lane, The Complexity of Self Government: Politics from the Bottom Up Review by Jon D. Miller

Lida Maxwell, Insurgent Truth: Chelsea Manning and the Politics of Outsider Truth-Telling Review by Candice Delmas

Cary J. Nederman, The Bonds of Humanity: Cicero's Legacies in European Social and Political Thought, ca. $1100-$ ca. 1550 Review by David Fott

Gina Schouten, Liberalism, Neutrality, and the Gendered Division of Labor Review by Ruth Abbey

930 William Selinger, Parliamentarism: From Burke to Weber Review by Ewa Atanassow

lain Stewart, Raymond Aron and Liberal Thought in the Twentieth Century Review by Gianna Englert

Bob Pepperman Taylor, Lessons from Walden: Thoreau and the Crisis of American Democracy Review by Jennet Kirkpatrick

935 J. S. Maloy, Smarter Ballots: Electoral Realism and Reform

Sean Ingham, Rule by Multiple Majorities: A New Theory of Popular Control Review by Emilee Chapman

Jeffrey Friedman, Power without Knowledge: A Critique of Technocracy Review by Alfred Moore

938 Carlo Invernizzi Accetti, What Is Christian Democracy? Politics, Religion and Ideology Review by Alexander Kirshner

939 Jack Knight and Melissa Schwartzberg, Political Legitimacy: NOMOS LXI Review by Enzo Rossi

941 Rebecca LeMoine, Plato's Caves: The Liberating Sting of Cultural Diversity Review by Tae-Yeoun Keum

942 Bernd Reiter, Constructing the Pluriverse: The Geopolitics of Knowledge Review by George Ciccariello-Maher

\section{AMERICAN POLITICS}

944 Carrie N. Baker, Fighting the US Youth Sex Trade: Gender, Race, and Politics Review by Samantha Majic

945 Loren Collingwood and Benjamin Gonzalez O’Brien, Sanctuary Cities: The Politics of Refuge Review by Álvaro José Corral

947 Roderick P. Hart, Trump and Us: What He Says and Why People Listen Review by Matthew Eshbaugh-Soha

948 Laura S. Hussey, The Pro-Life Pregnancy Help Movement: Serving Women or Saving Babies? Review by Renée Ann Cramer

950 Melissa K. Merry, Warped Narratives: Distortion in the Framing of Gun Policy Review by Robert J. Spitzer

951 Kimberly K. Smith, The Conservation Constitution: The Conservation Movement and Constitutional Change, 1870-1930 Review by Richard N. L. Andrews

952 Emily Sydnor, Disrespectful Democracy: The Psychology of Political Incivility Review by Nathan P. Kalmoe

954 Katherine Levine Einstein, David M. Glick, and Maxwell Palmer, Neighborhood Defenders: Participatory Politics and America's Housing Crisis Review by Clayton Nall

955 Niambi Michele Carter, American while Black: African Americans, Immigration, and the Limits of Citizenship Review by Jane Junn

957 Brian R. Calfano and Nazita Lajevardi, Understanding Muslim Political Life in America: Contested Citizenship in the Twenty-First Century Review by Kassra A.R. Oskooii

Andrew H. Sidman, Pork Barrel Politics: How Government Spending Determines Elections in a Polarized Era Review by Jeffrey Lazarus

959 John J. Pitney, Jr., After Reagan: Bush, Dukakis, and the 1988 Election Review by Daniel E. Ponder

961 Paul Frymer, Building an American Empire: The Era of Territorial and Political Expansion Review by Colin D. Moore

\section{COMPARATIVE POLITICS}

962 Penelope Anthias, Limits to Decolonization: Indigeneity, Territory, and Hydrocarbon Politics in the Bolivian Chaco Review by Karleen Jones West

964 Nick Clarke, Will Jennings, Jonathan Moss, and Gerry Stoker, The Good Politician: Folk Theories, Political Interaction, and the Rise of Anti-Politics

Review by Russell J. Dalton 
Kira D. Jumet, Contesting the Repressive State: Why Ordinary Egyptians Protested During the Arab Spring Review by Nermin Allam

Ramazan Kılınç, Alien Citizens: The State and Religious Minorities in Turkey and France Review by Şener Aktürk

Stephanie J. Rickard, Spending to Win: Political Institutions, Economic Geography, and Government Subsidies Review by Scott Morgenstern

969 Aili Mari Tripp, Seeking Legitimacy: Why Arab Autocracies Adopt Women's Rights Review by Lihi Ben Shitrit

Manuel Vogt, Mobilization and Conflict in Multiethnic States Review by Idean Salehyan

Zhenqing Zhang, Intellectual Property Rights in China Review by Susan K. Sell

Jiwei Ci, Democracy in China: The Coming Crisis Review by Joseph Fewsmith

Amit Ahuja, Mobilizing the Marginalized: Ethnic Parties without Ethnic Movements Review by Adam Ziegfeld

Anna K. Boucher and Justin Gest, Crossroads: Comparative Immigration Regimes in a World of Demographic Change Review by Hannah M. Alarian

Alexandra Délano Alonso, From Here and There: Diaspora Policies, Integration, and Social Rights Beyond Borders Review by Louis DeSipio

Laura Dudley Jenkins, Religious Freedom and Mass Conversion in India Review by Amit Ahuja

981 Adam Michael Auerbach, Demanding Development: The Politics of Public Goods Provision in India's Urban Slums Review by Vineeta Yadav

Gwyneth H. McClendon and Rachel Beatty Riedl, From Pews to Politics: Religious Sermons and Political

Participation in Africa Review by Elizabeth Sheridan Sperber

Lisa Blaydes, State of Repression: Iraq under Saddam Hussein Review by Ariel I. Ahram

Dörthe Engelcke, Reforming Family Law: Social and Political Change in Jordan and Morocco Review by Iza Hussin

Yue Hou, The Private Sector in Public Office: Selective Property Rights in China Review by Lizhi Liu

Steven T. Brooke, Winning Hearts and Votes: Social Services and the Islamist Political Advantage Review by Quinn Mecham

Nils B. Weidmann and Espen Geelmuyden Rød, The Internet and Political Protest in Autocracies Review by Megan MacDuffee Metzger

\section{INTERNATIONAL RELATIONS}

991 Mia Bloom and John Horgan, Small Arms: Children and Terrorism Review by Ami Pedahzur

992 David Cortright, Conor Seyle, and Kristen Wall, Governance for Peace: How Inclusive, Participatory and Accountable Institutions Promote Peace and Prosperity

Jaroslav Tir and Johannes Karreth, Incentivizing Peace: How International Organizations Can Help Prevent Civil Wars in Member Countries Review by Susanna P. Campbell

Richard C. Eichenberg, Gender, War, and World Order: A Study of Public Opinion Review by Laura Sjoberg

996 Yagil Levy, Whose Life Is Worth More? Hierarchies of Risk and Death in Contemporary Wars Review by William A. Boettcher III

997 Benjamin Meiches, The Politics of Annihilation: A Genealogy of Genocide Review by George Andreopoulos

999 Adam Moore, Empire's Labor: The Global Army That Supports U.S. Wars Review by Deborah Avant

1000 George E. Shambaugh, Oracles, Heroes or Villains: Economic Policymakers, National Politicians and the Power to Shape Markets Review by Rodney Bruce Hall

1001 Pamina Firchow, Reclaiming Everyday Peace: Local Voices in Measurement and Evaluation after War Review by Naazneen $\mathrm{H}$. Barma

\section{David Brenner, Rebel Politics: A Political Sociology of Armed Struggle in Myanmar's Borderlands} Review by Jenny Hedström 
1004 Courtenay R. Conrad and Emily Hencken Ritter, Contentious Compliance: Dissent and Repression under International Human Rights Law

Review by Christian Davenport

1006 Alasdair Roberts, Strategies for Governing: Reinventing Public Administration for a Dangerous Century Review by Jennifer L. Selin

1007 Ben Wellings and Andrew Mycock, The Anglosphere: Continuity, Dissonance and Location Review by Inderjeet Parmar

1009 Rita Floyd, The Morality of Security: A Theory of Just Securitization Review by Anthony Burke

1011 Review Index 


\section{(apSA PREPRINTS AMERICAN POLITICAL SCIENCE ASSOCIATION}

\section{Now Live}

An exciting, new open research initiative and venue for the rapid posting of early research outputs in political science

\section{Key Benefits}

Free to post content

All content will be Open Access and free to the end user

Accepts all types of political science research, broadly defined

Authors retain copyright
- A non-profit partnership between APSA and Cambridge University Press

Advance the visibility and feedback for your work

Rapid posting, with 3-5 business day turnaround for content checks

See more:

cambridge.org/apsa-preprints 